\title{
Release of thymol from plasticized poly(vinyl chloride) (Rapid communication)
}

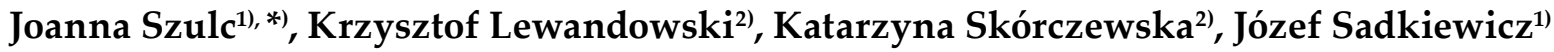 \\ DOI: dx.doi.org/10.14314/polimery.2018.11.12
}

\begin{abstract}
The aim of the study was to assess the possibility of using thymol as a potential modifier of the bioactive properties of plasticized poly(vinyl chloride) (PVC). For this purpose, a test of releasing the active substance - thymol - from modified plasticized PVC to water was performed. The higher the thymol concentration in the polymer matrix, the more substance was released during the first days of storage. The ability of the produced materials to gradually release thymol was found, which qualifies them as materials that can be useful for the production of active packaging.
\end{abstract}

Keywords: modified plasticized poly(vinyl chloride), active packaging materials, thymol, releasing of active substance.

\section{Uwalnianie tymolu z plastyfikowanego poli(chlorku winylu)}

Streszczenie: Oceniano możliwość wykorzystania tymolu jako dodatku aktywnego do poli(chlorku winylu) (PVC). Zbadano uwalnianie do wody substancji aktywnej z modyfikowanego PVC. Im większy był udział tymolu w materiale polimerowym, tym więcej substancji aktywnej migrowało do wody w pierwszych dniach przechowywania. Stwierdzono zdolność otrzymanych materiałów do stopniowego uwalniania tymolu, co kwalifikuje je jako przydatne do produkcji aktywnych opakowań.

Słowa kluczowe: modyfikowany plastyfikowany poli(chlorek winylu), aktywne materiały opakowaniowe, tymol, uwalnianie aktywnej substancji.

In the era of food management globalization, special consideration should be given to the health safety of food [1]. Consumers more and more often choose minimally processed food while expecting that it will be easy to prepare and remain suitable for consumption for a long time $[2,3]$. This poses a great challenge to the food producers. Searches for new solutions aimed primarily at retaining the original organoleptic features of food and protecting the consumer are progressing towards manufacturing active and smart packagings $[4,5]$.

In accordance with EU Regulation No. 1935/2004 on materials and articles intended to come into contact with food, active materials and products intended for contact with food should be developed in such a manner as to contain "active" ingredients that are designed to be gradually released into the food or to absorb substances from the food. Active packaging contributes to prolong-

1) University of Science and Technology, Faculty of Chemical Technology and Engineering, Department of Food Technology and Engineering, Seminaryjna 3, 85-326 Bydgoszcz, Poland.

2) University of Science and Technology, Faculty of Chemical Technology and Engineering, Department of Polymer Technology and Protective Coatings, Seminaryjna 3, 85-326 Bydgoszcz, Poland.

*) Author for correspondence; e-mail: joanna.szulc@utp.edu.pl ing the minimum durability date of the food and may contain modern solutions, such as sensors for monitoring the product parameters or antibacterial compounds included in the material of the packaging. The purpose of substances introduced to the matrix is primarily to protect the food against spoilage, while not worsening its properties [2]. The addition of a biocidal compound to the polymer material is made during manufacture of the packaging materials intended for transporting medicines and plant-protection products, in the production of household equipment (outer coatings of refrigerators or washing machines), textiles (e.g., synthetic nylon fiber with nanosilver), implants or other medical appliances $[6,7]$. An increase in interest in the application of polymer materials with the addition of active substances intended for contact with food has also been observed [3]. The production of new bioactive materials may cause authorization problems in the food industry, as well as affect recycling [8-10].

There are various methods of manufacturing active packagings to be used in the food industry, which include the application or adsorption of an active biocidal substances on the packaging surface or the addition of the active substance to the polymer [4, 11, 12]. A very common solution used in industry is the attachment of sachets/bags with antimicrobial substances to the food 
being packaged. This solution has become widespread in the meat industry, where portioned meat is placed in a package with a sachet made of fibrous materials saturated with biocidal substances, e.g., organic acids or surfactants. In addition to counteracting the deterioration of the meat, this insert also performs the function of a leakage absorber. Another method of adding an active substance in a separate container is placing sachets with oxygen and moisture absorbents and gaseous ethanol generators in the package [13].

A large group of biocidal substances are sensitive to heat effects at high temperatures. For this reason they may not be added to the polymer material directly during processing. However, this is the way the package and foodstuff contact surface might best be coated with an active substance. Proteins and peptides are of particular importance in the case at hand owing to their amphoteric nature [14]. Of great importance in the active packaging material creation process are also organic acids and their anhydrides, such as propionic, benzoic, sorbic, acetic, lactic, and malic acids. It seems also very attractive to utilize the biocidal properties of the natural extracts of spices, fruits or plants, such as cinnamon, thyme, horseradish, etc. [11, 15-17].

One such compound is thymol (2-isopropyl-5-methylphenol). This is an organic compound of the terpene group. Together with carvacrol (its' isomer), thymol is a component of ethereal oils occurring in thyme, oregano and savory [18]. It forms colorless crystals with a strong smell characteristic of thyme. Its biocidal properties were utilized in ancient times for mummifying corpses. Thymol shows a strong bactericidal, antifungal, antipyogenic, antiputrefactive, dehydrating and corrosive action (when administered at higher concentrations) [19]. Moreover, some viruses, saprophages and parasites show sensitivity to thymol [20]. As a natural antiseptic substance, thymol is used in the food industry.

The biological, chemical, and physical interactions between the food, package, and the ambient environment in the case of most food products have a great impact on their shelf life. Active packaging materials should interact with food, especially leading to a decrease or elimination of bacteria and microorganisms in food products that can: potentially spoil food, generate undesirable deteriorations in flavor, odor, color, sensory, and textural properties, and be harmful and dangerous to human health [21]. The main purpose of active packaging materials, which are made by incorporating the active substances into the polymer matrix, are too slowly and continuously release the biocidal additives over the required period of time and maintain a high concentration of the antimicrobial compound in the product. The aim of the undertaken research was to assess the possibility of using thymol as a potential modifier of the bioactive properties of plasticized poly(vinyl chloride).

\section{EXPERIMENTAL PART}

\section{Materials}

- S-70 poly(vinyl chloride) (Anwil S.A., Poland);

- Plasticizer [bis(2-ethylhexyl)adipate] (ADO) (supplied by Boryszew ERG S.A., Poland);

- Reagens CLX/743 stabilizer (Reagens S.P.A., Italy);

- Thymol crystals (POCH S.A., Poland).

\section{Production of bioactive materials}

PVC dry blends corresponding to the composition given in Table 1 were prepared successively in a Brabender Z-shape mixer. The bowl temperature was $95^{\circ} \mathrm{C}$ and the rotational speed of the mixing blades was $56 \mathrm{rpm}$. In the first stage of preparing the PVC compound, a plasticizer (ADO) was heated up in the mixer for one minute and then S-70 PVC, along with stabilizer and broken thymol crystals, were added.

The blending process was continued until the plasticizer had been totally absorbed into the PVC grains. Thus, the obtained blends were extruded using a Brabender single-screw laboratory extruder (screw diameter $15 \mathrm{~mm}$; $L / D=13$ ). The processing temperature was $130^{\circ} \mathrm{C}$ starting from the charging hopper and increased gradually along the cylinder to reach $150{ }^{\circ} \mathrm{C}$ at the extrusion head. Extrusion was conducted through a $3 \mathrm{~mm}$ - diameter $30 \mathrm{~mm}$ - long extruding die at a screw rotational speed of $50 \mathrm{rpm}$. The obtained extrudate was granulated and

$\mathrm{T}$ a $\mathrm{b} 1 \mathrm{e}$ 1. The composition of poly(vinyl chloride) compounds

\begin{tabular}{c|c|c|c|c}
\hline No. & $\begin{array}{c}\text { PVC } \\
\text { phr (wt \%) }\end{array}$ & $\begin{array}{c}\text { ADO } \\
\text { phr (wt \%) }\end{array}$ & $\begin{array}{c}\text { Thymol } \\
\text { phr (wt \%) }\end{array}$ & $\begin{array}{c}\text { Stabilizer } \\
\text { phr (wt \%) }\end{array}$ \\
\hline 1 & $100(66.0)$ & $50(33.0)$ & $0.00(0.0)$ & $1.5(1.0)$ \\
2 & $100(65.7)$ & $50(32.8)$ & $0.76(0.5)$ & $1.5(1.0)$ \\
3 & $100(65.3)$ & $50(32.7)$ & $1.53(1.0)$ & $1.5(1.0)$ \\
4 & $100(64.7)$ & $50(32.3)$ & $3.10(2.0)$ & $1.5(1.0)$ \\
5 & $100(49.65)$ & $100(49.65)$ & $0.00(0.0)$ & $1.5(0.7)$ \\
7 & $100(49.4)$ & $100(49.4)$ & $1.01(0.5)$ & $1.5(0.7)$ \\
8 & $100(49.15)$ & $100(49.15)$ & $2.04(1.0)$ & $1.5(0.7)$ \\
\end{tabular}


then pressed into $2 \mathrm{~mm}$ thick $200 \times 200 \mathrm{~mm}$ plates using a hydraulic press. The pressing temperature was $160^{\circ} \mathrm{C}$ and the pressure $5 \mathrm{MPa}$, while the total pressing duration was 3 minutes. From the obtained shapes, discs (diameter $=10 \mathrm{~mm}$ ) were cut, which were subsequently used for further testing.

\section{Methods of testing}

\section{Determination of the amount of released thymol}

Material specimens, each of a mass of approximately $2 \mathrm{~g}$ (10 discs), were placed in vessels with stoppers and flooded with $40 \mathrm{~cm}^{3}$ of distilled water and mixed every day of storage. The thymol concentration in the water solution was determined after 1, 6 and 10 days. The quantity of thymol released to the eluate was assayed following the methodology developed by Al-Abachi [22]. This method utilizes the reaction of thymol with procaine hydrochloride (Sigma-Aldrich). The orange-red product is then assayed spectrophotometrically at a wavelength of $474 \mathrm{~nm}$.

\section{Determination of the antimicrobial activity of PVC films}

The agar diffusion method was used to determine the antibacterial activity of PVC-thymol films. Polymer discs (10 $\mathrm{mm}$ diameter) were placed on the surface of the nutrient agar dishes (P-0122, BLT Sp. z o.o., Poland) freshly loaded with microorganisms from food sample. The food sample were radish sprouts with total mesophilic bacteria $\leq 106 / g$. The agar plates with discs were incubated at $37{ }^{\circ} \mathrm{C}$ for 3 days. The tests were carried out in triplicate. The inhibition zones were observed.

\section{RESULTS AND DISCUSSION}

The diagrams in Fig. 1 and Fig. 2 represent the dependence of thymol concentration in the water solution re-

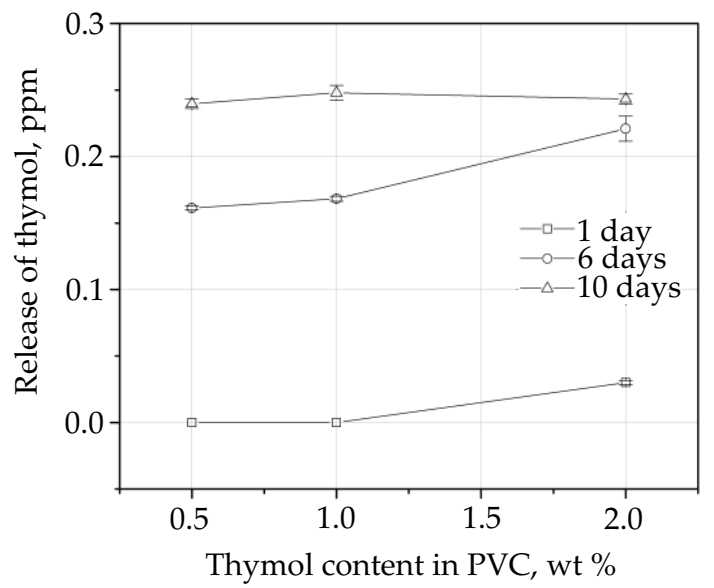

Fig. 1. The concentration of thymol in the eluate depending on the thymol content of PVC blends (50 phr of plasticizer) for varied elution duration leased from the PVC-thymol material with different concentration of plasticizer, respectively, after the 1st, 6th and 10th day storage in water. The release of thymol takes place in all of the fabricated materials. The active substance content of the eluate increased gradually with longer durations of solution action upon the material. For the materials exposed to water for 10 days, no distinct effect of the concentration of thymol, as well as the PVC plasticizer, on the ultimate quantity of the released active substance was observed. A similar relationship was confirmed by Guarda et al. in their study [18], who applied micro-encapsulated thymol to the packaging. The higher the thymol concentration, the more substance was released; however, after 10th day, further increases in concentration were insignificant. The study carried out by Ramos et al. [15] showed that thymol release from polypropylene (PP) films increased with longer times exposed to different media and reached an equilibrium after approximately $120 \mathrm{~h}$.

Higher plasticizer contents resulted in an increased release of the active substance in the first days of assaying. This phenomenon might be explained by reduced interactions between molecules of poly(vinyl chloride) and an increased migration of the plasticizer to the medium [23].

In Figs. 3 and 4, the inhibition zones of the obtained active materials are presented. In Fig. 3, the microorganisms grow on the whole surface of the nutrient agar plate. On the agar plate surface with antimicrobial PVC-thymol film (Fig. 4), a zone of microorganism growth inhibition can be seen. In the agar plate test, antimicrobial films are placed on a solid agar medium containing the microorganisms. A clear zone surrounding the film indicates antimicrobial diffusion from the film and subsequent growth inhibition (Fig. 4). The agar plate test method simulates wrapping of foods and may suggest what can happen when films contact contaminated surfaces and the antimicrobial agent migrates from the film to the food [1]. Thymol released from the material inhibited microorganism growth.

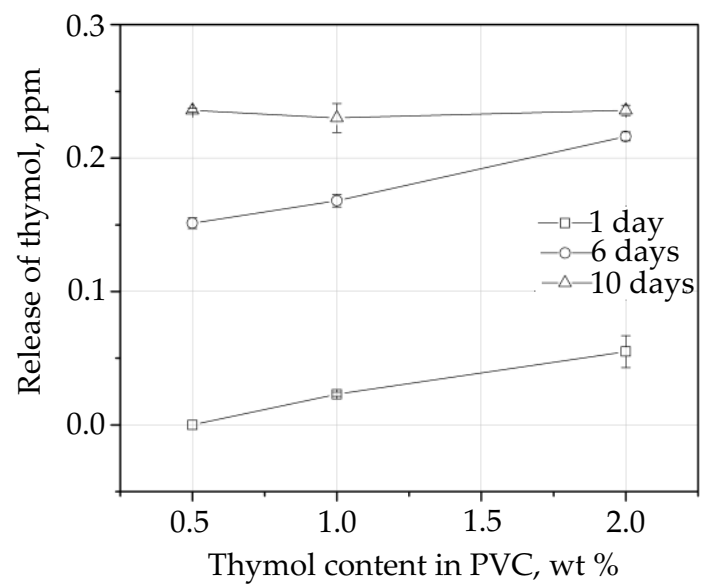

Fig. 2. The concentration of thymol in the eluate depending on the thymol content of PVC blends (100 phr of plasticizer) for varied elution duration 


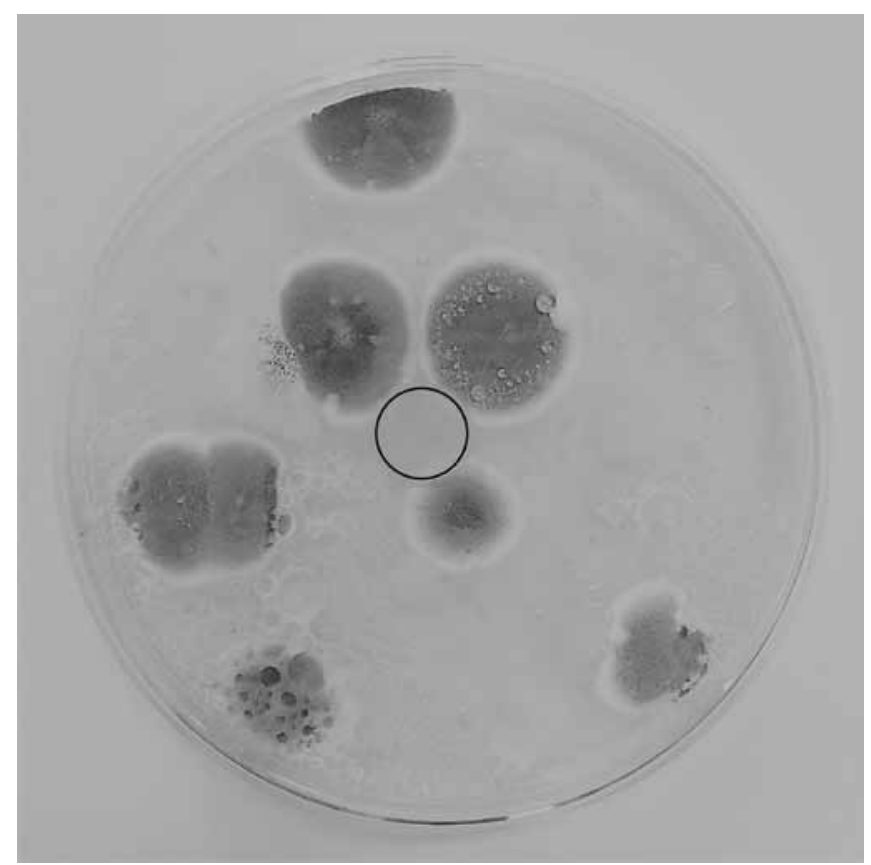

Fig. 3. Effect of antimicrobial PVC film (50 phr of plasticizer) without thymol incorporated into the polymer matrix on the microorganisms (agar diffusion method), PVC film is marked with a black circle

\section{CONCLUSIONS}

The examinations carried out allow the fabricated materials to be qualified as raw materials for the production of active packaging due to thymol release from the polymer matrix. The higher the thymol concentration, the more substance was released during the first days of storage. A higher content of plasticizer in the polymer matrix also increased the migration of active agent into the investigated medium. Therefore, according to the results, it is favorable to use an increased content of plasticizer in the new active packaging material. Enhanced release of thymol from the polymer matrix may probably improve the biostatic properties of developed packaging.

\section{REFERENCES}

[1] Appendini P., Hotchkiss J.H.: Innovative Food Science \& Emerging Technologies 2002, 3, 113. http://dx.doi.org/10.1016/S1466-8564(02)00012-7

[2] Mishra H.N., Sinija V.R.: Comprehensive Reviews in Food Science and Food Safety 2008, 7, 358. http://dx.doi.org/10.1111/j.1541-4337.2008.00049.x

[3] Jamróz E.: Polimery 2017, 62, 428. http://dx.doi.org/10.14314/polimery.2017.428

[4] Balasubramanian A., Rosenberg L.E., Yam K. et al.: The Journal of Applied Packaging Research 2009, 3, 193.

[5] Nowacka M.: Ważenie, dozowanie, pakowanie 2010, 4,46 .

[6] Kołodziejska J., Berner-Strzelczyk A., Piechota-Urbańska M.: Polimery w medycynie 2009, 39, 31.

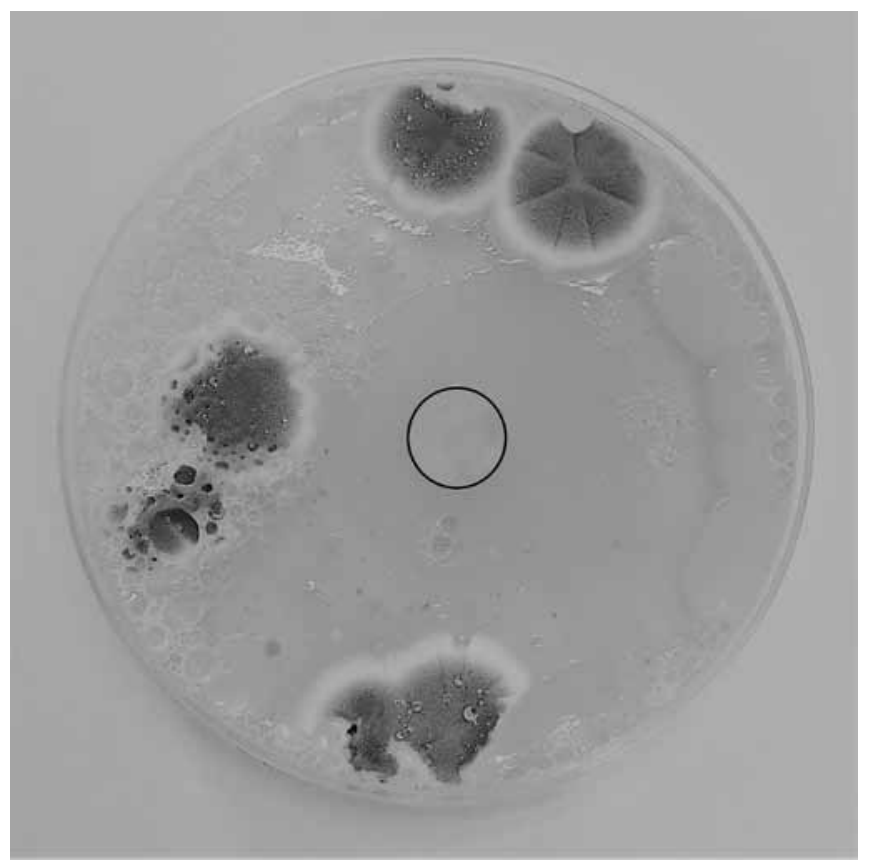

Fig. 4. Effect of antimicrobial PVC film (50 phr of plasticizer) containing thymol ( $2 \mathrm{wt} \%$ ) on the microorganisms (agar diffusion method), PVC film is marked with a black circle

[7] Dastjerdi R., Montazer M.: Colloids and Surfaces B: Biointerfaces 2010, 79, 5. http://dx.doi.org/10.1016/j.colsurfb.2010.03.029

[8] Kuciel S., Kuźniar P., Nykiel M.: Polimery 2018, 63, 31. http://dx.doi.org/10.14314/polimery.2018.1.5

[9] Kolasa D., Bajszczak A., Łukomska A. et al.: Polimery 2016, 61, 98. http://dx.doi.org/10.14314/polimery.2016.098

[10] Jurewicz M.: Polimery 2017, 62, 144. http://dx.doi.org/10.14314/polimery.2017.144

[11] Gniewosz M., Synowiec A., Dyrda M.: Biotechnologia 2009, 4, 40.

[12] Stepczyńska M.: „Studium plazmowego modyfikowania warstwy wierzchniej oraz metod sterylizacji materiałów biodegradowalnych", Wydawnictwo UKW, Bydgoszcz 2017.

[13] Brody A.L., Strupinsky E.R., Kline L.R.: "Active Packaging for Food Applications", Boca Raton, CRC Press LLC, 2001.

[14] Gómez-Heincke D., Martínez I., Partal P. et al.: Journal of the Science of Food and Agriculture 2016, 96, 3432. http://dx.doi.org/10.1002/jsfa.7525

[15] Ramos M., Jiménez A., Peltzer M. et al.: Journal of Food Engineering 2012, 109, 513. http://dx.doi.org/10.1016/j.jfoodeng.2011.10.031

[16] Malhotra B., Keshwani A., Kharkwal H.: Frontiers in Microbiology 2015, 6, 611. http://dx.doi.org/10.3389/fmicb.2015.00611

[17] Irkin R., Esmer O.K.: Journal of Food Science and Technology 2015, 52 (10), 6095. http://dx.doi.org/10.1007/s13197-015-1780-9 
[18] Guarda A., Rubilar J.F., Miltz J. et al.: International Journal of Food Microbiology 2011, 46, 144. http://dx.doi.org/10.1016/j.ijfoodmicro.2011.02.011

[19] Lee S.J., Umano K., Shibamoto T. et al.: Food Chemistry 2005, 91, 131.

http://dx.doi.org/10.1016/j.foodchem.2004.05.056

[20] Singh N., Singh R.K., Bhunia A.K.: Lebensmittel-Wissenschaft \& Technologie 2003, 36, 235.
http://dx.doi.org/10.1016/S0023-6438(02)00224-4

[21] Tawakkal I.S.M.A., Cran M.J., Miltz J. et al.: Journal of Food Science 2014, 79, R1477.

http://dx.doi.org/10.1111/1750-3841.12534

[22] Al-Abachi M.Q.: Baghdad Science Journal 2012, 9, 302.

[23] Piszczek K.: Polimery 2005, 50, 756.

Received 13 III 2018.

Revised version 14 VI 2018. 